\title{
Immunoglobulin D plasmablastic myeloma mimicking metastatic malignancy
}

\author{
Muhajir Mohamed $^{1,2 *}$, Wade Clarkson ${ }^{1}$ and Roya Arabi ${ }^{1}$ \\ ${ }^{1}$ Launceston General Hospital, Launceston, Australia \\ ${ }^{2}$ Launceston Clinical School, University of Tasmania, Australia
}

\begin{abstract}
Immunoglobulin D (IgD) myeloma is an uncommon subtype of multiple myeloma and accounts for less than $2 \%$ of all myeloma patients. Plasmablastic myeloma is a rare morphological variant of multiple myeloma with a poor prognosis, and its association with $\operatorname{IgD}$ paraprotein is extremely rare. We report a patient who had the diagnosis of IgD myeloma with plasmablastic morphology and presented with multiple FDG-PET avid bone lesions, mimicking metastatic malignancy.
\end{abstract}

\section{Case report}

An 80-year-old lady was referred for anaemia and generalized bone pains. Blood investigations revealed low haemoglobin of $90 \mathrm{~g} / \mathrm{L}$, high calcium $(2.72 \mathrm{mmol} / \mathrm{L})$ and elevated creatinine $(164 \mu \mathrm{mol} / \mathrm{L})$. Eight years prior, the patient developed cancer in her left breast and attained remission after radical mastectomy and chemotherapy. Clinically there were no mass lesions in the contralateral breast, lymphadenopathy or abdominal masses. ${ }^{18} \mathrm{~F}-\mathrm{FDG}$-PET scan was performed due to the history of breast cancer, which revealed extensive FDG-avid uptakes through out the skeleton, and in the bone marrow (Figure 1). Metastatic malignancy was the provisional diagnosis due to her past history of breast cancer. However no primary sites were identifiable and serum tumour markers such as CEA, CA19.9 and CA15.3 were within the reference ranges.

Since the differential diagnosis was multiple myeloma, serum protein electrophoresis was performed, which revealed a discrete paraprotein band in the gamma region. However, immunofixation electrophoresis was negative for standard heavy chain panel of IgG, IgM

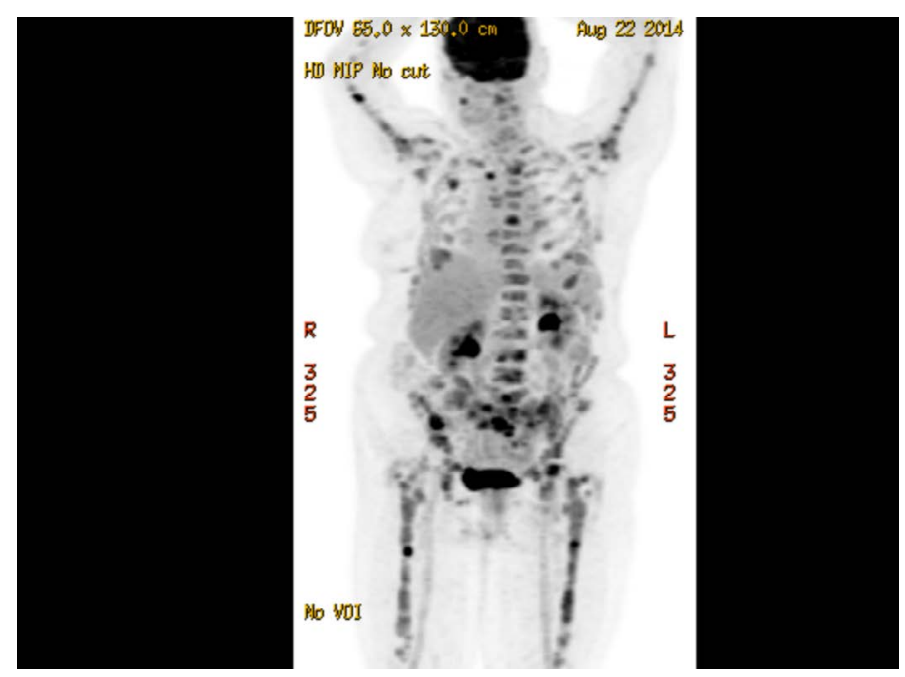

Figure 1. 18F-FDG-PET scan showed extensive FDG-avid uptakes in the skeleton and IgA. But a monoclonal band was noted in the kappa light chain lane and Bence-Jones protein (kappa) was detected in urine electrophoresis. Hence IFE using anti-IgD and anti-IgE were performed and a discrete IgD paraprotein band was demonstrated and quantified as $8840 \mathrm{mg} / \mathrm{l}$. There were no lytic or destructive bone lesions on skeletal CT scans despite multiple FDG-PET positive bone and marrow lesions. Bone marrow biopsy revealed diffuse infiltration by large and pleomorphic neoplastic cells containing eccentric nuclei, fine nuclear chromatin, prominent nucleoli and mitotic figures consistent with plasmablastic morphology (Figure 2). Immunohistochemical studies revealed strong surface positivity for CD138 on the neoplastic cells (Figure 3). $\operatorname{IgD}$ and kappa stains were also strongly positive in the cytoplasm of those cells (Figures 4 and 5), but negative for CD20, IgA, IgG, IgM and lambda and EBER. The diagnosis was plasmablastic myeloma of IgD-kappa subtype. Fluorescent in-situ hybridization testing on bone marrow was negative for high risk genetic rearrangements such as FGFR3-IGH, IGH-MAF and TP53. Serology tests for viral infections - HIV, Hepatitis B, Hepatitis C, EBV-IgM and CMV-IgM were negative. The patient was treated with bortezomib based regimen and bisphosphonates and she demonstrated good clinical response with drop in IgD paraprotein values to $1800 \mathrm{mg} / \mathrm{l}$ after 4 months; however, she developed fulminant septicemia and died two months later.

\section{Discussion}

Immunoglobulin $\mathrm{D}(\mathrm{IgD})$ myeloma accounts for less than $2 \%$ of all myeloma patients $[1,2]$. IgD myeloma is characterized by smaller size or absence of serum M-protein, predominance of lambda light chains, and high incidence of renal impairment, extraosseous involvement, hypercalcemia and amyloidosis [3-6]. Since conventional serum protein electrophoresis and immunoglobulin quantification assays are tailored to detect the more common IgG and IgA sub-types of myeloma, the diagnosis of IgD myeloma can be difficult [7].

${ }^{*}$ Correspondence to: Muhajir Mohamed, DM (Clin Haem), FRCPA, FRACP Consultant Haematologist, Northern Cancer Centre, Launceston General Hospital, Launceston, Australia, E-mail: muhajirbm@yahoo.com

Received: July 12, 2018; Accepted: July 21, 2018; Published: July 24, 2018 


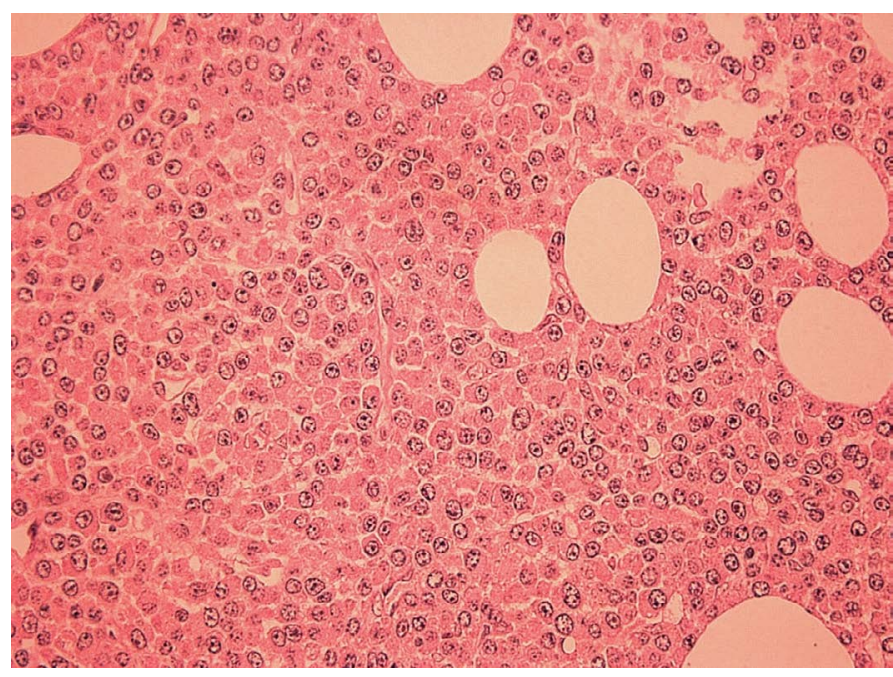

Figure 2. Bone marrow biopsy revealed diffuse infiltration by plasmablasts (H\&E stain; 400x magnification)

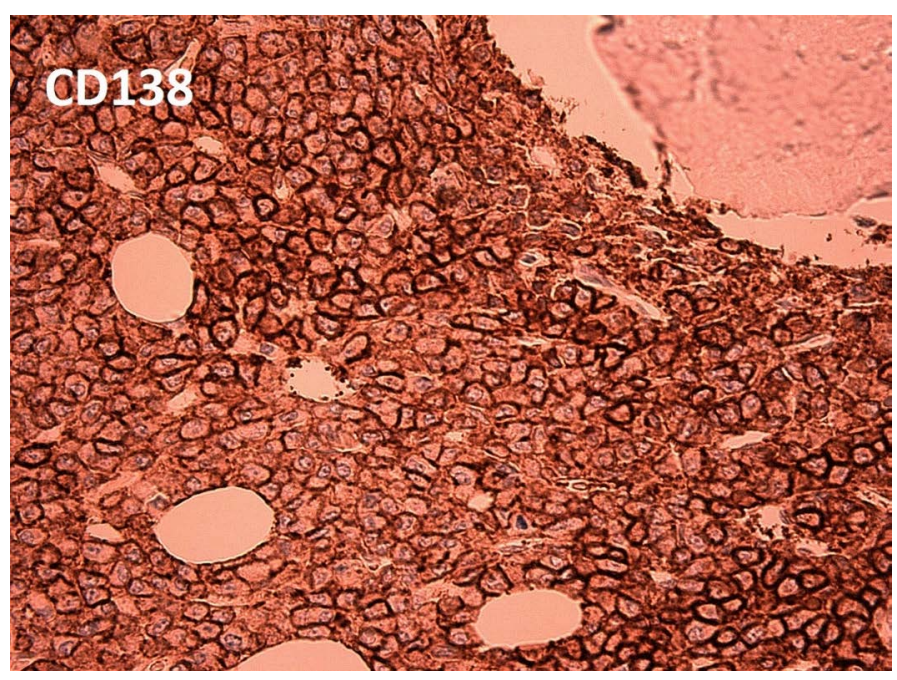

Figure 3. CD138 stain shows strong surface positivity (400x magnification)

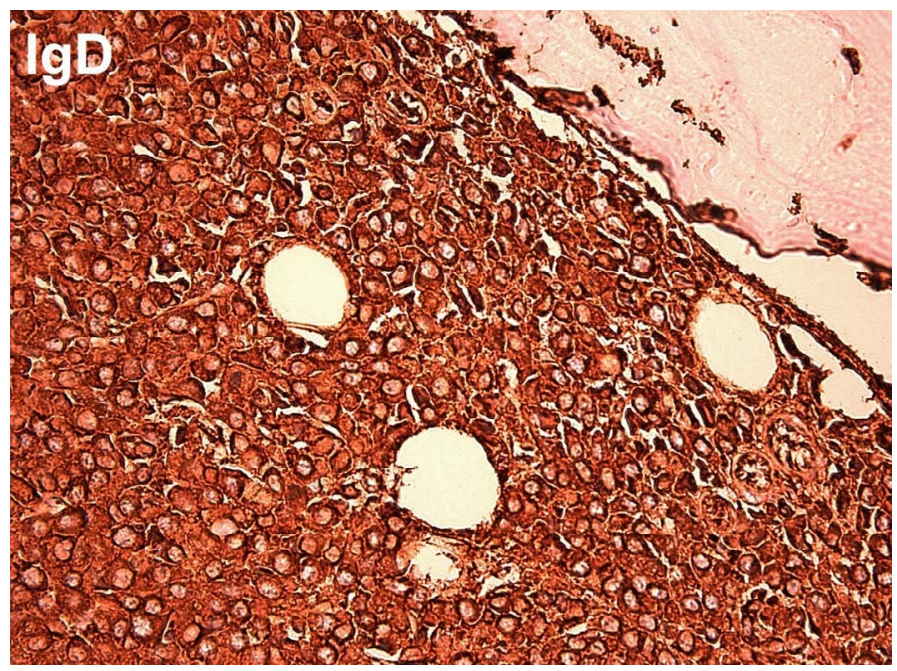

Figure 4. IgD stain shows strong cytoplasmic positivity (400x magnification)

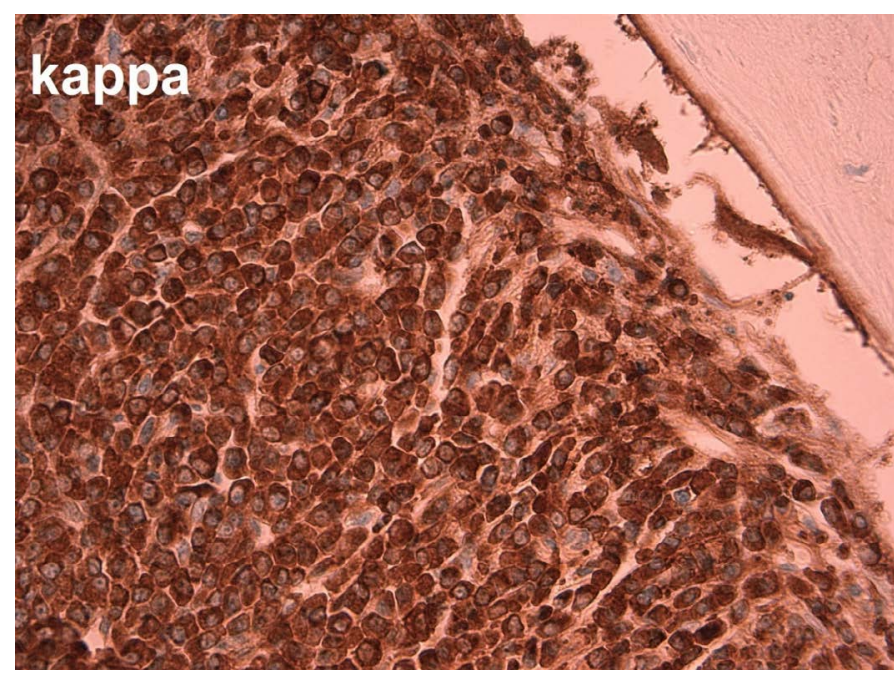

Figure 5. Kappa stain shows strong cytoplasmic positivity (400x magnification)

Plasmablastic myeloma is a rare morphological variant $(\sim 10 \%)$ of multiple myeloma and generally follows an aggressive clinical course with poor prognosis [8]. Morphologically plasmablasts differ from plasma cells due to the presence of larger nucleus size, fine nuclear chromatin pattern, prominent nucleolus, moderate rim of basophilic cytoplasm and absence of perinuclear hof [9].

In a study by Bartl et al. histological features of 674 cases of multiple myeloma were analyzed and classified based on cell size, cytoplasmic structure, and nuclear configuration of the neoplastic plasma cells. Plasmablastic type accounted for $2 \%$ and the rarest subtype in this series. This subtype showed the most aggressive clinical course among the morphological subtypes. Among plasmablastic myeloma, 60\% had IgG paraprotein, $20 \%$ had IgA paraprotein, and the $20 \%$ with light chain, with no cases of IgD paraprotein IgD in the series [10].

Plasmablastic myeloma and plasmablastic lymphoma may exhibit similar morphological features histopathologically and cytologically with the neoplastic cells showing blastic features, with scanty plasmacytic differentiation [11]. Both these conditions demonstrate immunophenotype of plasma cells (CD38+, CD138+ and CD20-). However, plasmablastic lymphoma is usually associated with HIV infection and the malignant cells are EBV-infected in majority of cases and the main difference is EBV positivity in plasmablastic lymphoma, but negative in plasmablastic myeloma $[10,12]$.

This case highlights the extremely rare association of $\operatorname{IgD}$ variant of multiple myeloma with plasmablastic morphology. Metastatic solid organ malignancy was initially suspected based on the presence of multiple FDG-positive skeletal lesions without lytic bone lesions, however further investigations confirmed IgD multiple myeloma.

\section{Author contributions}

Muhajir Mohamed - haematologist who diagnosed and treated the patient, performed literature review and wrote the manuscript. Wade Clarkson - biochemist who performed the diagnostic investigations, and checked the manuscript. Roya Arabi - clinical haematology registrar who helped in collecting details of the patient, and literature review and checked the manuscript. 


\section{Conflicts of interest}

None to disclose for all authors.

\section{References}

1. Bladé J, Kyle RA (1999) Nonsecretory myeloma, immunoglobulin D myeloma, and plasma cell leukemia. Hematol Oncol Clin North Am 13: 1259-1272. [Crossref]

2. Ishida M, Hodohara K, Okuno H, Yoshii M, Horinouchi A, et al. (2014) IgD plasmablastic myeloma: a case report with emphasis on the cytological features. Int $J$ Clin Exp Pathol 7: 1250-1254. [Crossref]

3. Bladé J, Lust JA, Kyle RA (1994) Immunoglobulin D multiple myeloma: presenting features, response to therapy, and survival in a series of 53 cases. J Clin Oncol 12: 2398-2404. [Crossref]

4. Shimamoto Y, Anami Y, Yamaguchi M (1991) A new risk grouping for IgD myeloma based on analysis of 165 Japanese patients. Eur J Haematol 47: 262-267. [Crossref]

5. Pisani F, Petrucci MT, Giannarelli D, Bongarzoni V, Montanaro M, et al. (2012) IgD multiple myeloma a descriptive report of 17 cases: survival and response to therapy. $J$ Exp Clin Cancer Res 31: 17. [Crossref]
6. Sinclair D (2002) IgD myeloma: clinical, biological and laboratory features. Clin Lab 48: 617-622. [Crossref]

7. Kuliszkiewicz-Janus M, Zimny A, Sokolska V, SaĹźiadek M, Kuliczkowski K (2005) Immunoglobulin D myeloma--problems with diagnosing and staging (own experience and literature review). Leuk Lymphoma 46: 1029-1037. [Crossref]

8. Greipp PR, Raymond NM, Kyle RA, O'Fallon WM (1985) Multiple myeloma: significance of plasmablastic subtype in morphological classification. Blood 65: 305310. [Crossref]

9. Goasguen JE, Zandecki M, Mathiot C, Scheiff JM, Bizet M, et al. (1999) Mature plasma cells as indicator of better prognosis in multiple myeloma. New methodology for the assessment of plasma cell morphology. Leuk Res 23: 1133-1140. [Crossref]

10. Bartl R, Frisch B, Fateh-Moghadam A, Kettner G, Jaeger K, et al. (1987) Histologic classifi- cation and staging of multiple myeloma. A ret- rospective and prospective study of 674 cases. Am J Clin Pathol 87: 342-355. [Crossref]

11. Mettler TN, Holman CJ, McKenna RW, Pambuccian SE (2012) Plasmablastic myeloma in ascitic fluid. Diagn Cytopathol 40: 806-809. [Crossref]

12. Vega F, Chang CC, Medeiros LJ, Udden MM, Cho-Vega JH, et al. (2005) Plasmablastic lymphomas and plasmablastic plasma cell myelomas have nearly identical immunophenotypic profiles. Mod Pathol 18: 806-815. [Crossref]

Copyright: (C2018 Mohamed M. This is an open-access article distributed under the terms of the Creative Commons Attribution License, which permits unrestricted use, distribution, and reproduction in any medium, provided the original author and source are credited. 